\title{
FROM PETISTA WAY TO BRAZILIAN WAY: HOW THE PT CHANGES IN THE ROAD
}

\author{
Benjamin Goldfrank \\ Brian Wampler
}

\begin{abstract}
Resumo
Quando Luiz Inácio Lula da Silva venceu a disputa presidencial em 2002, ele e seu Partido dos Trabalhadores (PT) tiveram a maioria dos observadores convencidos de que esta era uma nova fase para a democracia do país. Afinal o PT tinha construído uma reputação de mais de vinte anos para um bom governo e ética na política. Apesar disso o governo Lula tem sido severamente minado por escândalos de corrupção, que surpreendeu até o mais cínico dos observadores do PT e fomentou amplo descontentamento entre muitos dos antigos defensores do partido. Esse artigo expõe quatro vertentes de explicação para a queda da simpatia do PT, envolvendo: o elevado custo das eleições brasileiras, as decisões estratégicas da facção dominante do partido, restrições econômicas sobre uma eventual administração Lula e sobre as dificuldades do sistema multipartidário.
\end{abstract}

Palavras-chave: Corrupção; Partidos Políticos; Partido dos Trabalhadores; Mensalão; Presidencialismo.

\begin{abstract}
When Luiz Inácio 'Lula' da Silva won Brazil's presidency in 2002, he and his Workers' Party (PT) had most observers convinced that this was a watershed moment for the country's democracy. After all, the PT had built a reputation for over twenty years for good government and ethics in politics. Yet Lula's government has been severely undermined by corruption scandals, which surprised the most cynical PT-watchers and fostered broad disillusionment among many long-time PT supporters. This article lays out four interweaving strands of explanation for the PT's fall from grace, involving: the high cost of Brazilian elections, the strategic decisions of the party's dominant faction, economic constraints on an eventual Lula administration, and the difficulties of multi-party presidential systems.
\end{abstract}

Key-words: Corruption; Political Parties; Workers Party (PT); Mensalão; Presidential System.

\section{From Good Government to Politics as Usual: How the Workers' Party (PT) Lost its Way}

When Luiz Inácio 'Lula' da Silva won Brazil's presidency in 2002, he and his Workers' Party (PT) had most observers convinced that this was a watershed moment for the country's democracy. The victory of this former shoeshine boy, metal worker, and union leader symbolised to many the arrival to power of Brazil's excluded masses and the opportunity to put into practice the PT way of governing, lauded as 
participatory, redistributive, and, above all, transparent. Five years and several astounding corruption scandals later, few illusions remain. Lula won the second round of the 2006 election with $61 \%$ of the vote, but his inability to win in the first round is largely attributable to perceptions that the PT has been involved in the very types of behaviours that they spent twenty-five years publicly denouncing. The PT has been gravely wounded by the scandals, starting with the so-called mensalão, or monthly bribe scandal, which brought resignations from the party's top leaders and members of Lula's cabinet as well as renewed calls for reforming Brazil's political institutions. The mensalão involves allegations of regular payments to the PT government's congressional allies in addition to illegal, off-the-books campaign donations (known as the caixa dois) and improper use of public funds and contracts to secure those donations. Brazil has seen its fair share of scandals over the years -from the impeachment of its first democratically elected president after the transition, Fernando Collor, to the purported "vote-buying" that accompanied Fernando Henrique Cardoso's successful attempt to amend the constitution to allow for his re-election-so what was surprising about the mensalão was the party involved.

From its inception in the early 1980s, the PT stood for incorruptibility, refusing to accept the military's offer of indirect presidential elections during democratization, leading the charge for investigating President Collor, and emphasizing clean government at the municipal level, where it was increasingly successful. By the time of the 2002 race, the PT had earned a reputation among voters as Brazil's most honest party (GOLDFRANK, 2004, p. 207-208; Fundação Perseu Abramo, 2006). Scholars of the country's notoriously weak party system regularly noted the PT's outlier status as virtually the only ideologicallydriven, internally democratic, and disciplined party. Lula's 2002 presidential campaign stressed the party's ethics and anti-corruption message. Its first commercial showed rats chewing on a Brazilian flag and the caption: "Either we finish them off or they finish off Brazil. Ciao, corruption - a campaign by the PT and the Brazilian people" (MARKUN, 2004, p. 313-314). Just a few years later, an aide to the PT president's 
brother was caught in Brasília's airport with 100,000 dollars in his underwear ${ }^{1}$, Lula's finance minister and chief of staff resigned, as did the PT's president, secretary-general, and treasurer, all tied to the mensalão scandal. How did the PT move from a party that built its party brand on honesty and transparency to a party in which high-ranking officials were engaged in systematic forms of corruption?

Lula tried to minimise the scandal in the press, saying that the PT had only done what other parties do, but that is precisely the point: "In the end - and this is the mother of all issues - many people voted for the PT because the party did not do what the others do" (GOIS, 2005, p. 14). Why would the party put its hard-fought, vote-getting reputation for good government at risk? Why did it change course to become like the rest? Or, as its conservative opponents have long asserted, was the PT's supposed ethical patrimony simply a farce all along? This article lays out four interweaving strands of explanation, involving: the high cost of Brazilian elections, the strategic decisions of the party's dominant faction (the Campo Majoritário or Majority Camp), economic constraints on an eventual Lula administration, and the difficulties of establishing legislative majorities in multi-party presidential systems.

These four interweaving strands have their roots in institutional, economic, and governance processes. The predominant mode of explanation in contemporary political science is institutionalist, but we argue that it is insufficient to only consider institutional factors due to tremendous economic and societal demands faced by elected officials in Brazil (SAMUELS, 2003; AMES, 2001; HUNTER and POWER, 2007). The PT's fall from grace is best explained by the political institutional pressures that induced party leaders to change their strategies, by national and international markets that provided a limited range of options, and by intra-party conflicts regarding the strategies that should be utilized to govern effectively. Any one of these explanations by itself offers an incomplete picture. Only by looking at all four interweaving ${ }^{1}$ The aide also had 209,000 reais (about US $\$ 100,000$ ) in his suitcase (ESTADO DE SÃO PAULO, July 9, 2005, p. 1). As the main purpose of this article is to explain the reasons behind the PT's descent into corruption rather than provide an exhaustive accounting, we only use the names of the key politicians. 
strands can we explain why the PT fell from grace. First we must describe the party's rise and acquisition of its reputation for ethics.

\section{Rising PT Fortunes}

The PT (Partido dos Trabalhadores) was founded in 1979 by a diverse group of activists who shared a commitment to ending Brazil's military dictatorship, establishing democracy, and implementing some form of socialism. Unions, social movements, intellectuals, and progressive sectors of the middle class formed the base of the new party (KECK, 1992). The PT was established as a bottom-up party, in which party members had voice and vote on policy decisions, political orientation, and leadership selection. The PT established the modo petista de governar (PT way of governing), which was used as a governing strategy as well as a party branding strategy (GOLDAFRANK, 2004; NYLEN, 2000). The PT placed strong emphasis on internal democracy, allowing members to practice democracy and giving minority factions the opportunity to influence their fellow party members. Nonetheless, within the context of PT democracy, a dominant faction - the Campo Majoritário - emerged in the mid-1990s. Minority groups did have voice, but control of the PT has been in the hands of Lula, José Dirceu, and their São Paulo allies since at least 1995. Internal democratic procedures have encouraged minority factions to remain in the party because there is a shared understanding that the PT represents a new way of conducting politics that would eventually change Brazil. While the party never explicitly defined the socialism it sought, it did uphold a strong ideological commitment to the inversion of priorities, which refers to the using of the state-local, state, and federal governments-to re-orient Brazil away from its traditionally unequal, exclusionary political and economic practices.

In order to overhaul Brazil, the PT has long advocated a twotrack strategy. The twin emphases include a social struggle, which occurs by building a movement from the ground up that is capable of engaging in direct political action to advance PT causes and an electoral struggle, which became increasingly important and increasingly focused 
on elections for executive positions. Lula has been at the centre of the PT since its founding in 1980 and is closely associated with the Campo Majoritário, which increasingly favoured a focus on winning elections over social movement-style activism (FREIRE DE LACERDA, 2002). Indeed, the electoral fortunes of the PT have improved steadily and dramatically since its first efforts in 1982 (see Figure 1).

Figure 1 - PT election results, 1982-2006

\begin{tabular}{|r|c|c|c|c|c|c|c|}
\hline Election Year & $\mathbf{1 9 8 2}$ & $\mathbf{1 9 8 6}$ & $\mathbf{1 9 9 0}$ & $\mathbf{1 9 9 4}$ & $\mathbf{1 9 9 8}$ & $\mathbf{2 0 0 2}$ & $\mathbf{2 0 0 6}$ \\
\hline Governors & 0 & 0 & 0 & 2 & 3 & 3 & 4 \\
\hline Federal Deputies & 8 & 16 & 35 & 49 & 58 & 91 & 83 \\
\hline \% of Chamber & $1.70 \%$ & $3.30 \%$ & $7 \%$ & $10 \%$ & $11 \%$ & $18 \%$ & $16 \%$ \\
\hline
\end{tabular}

\begin{tabular}{|r|c|c|c|c|c|c|c|}
\hline Election Year & $\mathbf{1 9 8 2}$ & $\mathbf{1 9 8 5}$ & $\mathbf{1 9 8 8}$ & $\mathbf{1 9 9 2}$ & $\mathbf{1 9 9 6}$ & $\mathbf{2 0 0 0}$ & $\mathbf{2 0 0 4}$ \\
\hline Mayors & 1 & 2 & 38 & 54 & 110 & 187 & 411 \\
\hline $\begin{array}{r}\text { Mayors in } \\
\text { Capital Cities }\end{array}$ & 0 & 1 & 3 & 4 & 2 & 6 & 6 \\
\hline
\end{tabular}

Source: Tribunal Superior Eleitora (www.tse.gov.br)

When the PT won mayoral and gubernatorial offices, the elected officials often emphasized participatory decision-making as a means to invert priorities, appeal to its social movement allies, demonstrates its commitment to honesty in office, and thereby build a base of support by distinguishing itself from Brazil's myriad other parties. The most famous case, Porto Alegre's Participatory Budgeting (PB), which captured the attention of PT activists and ordinary citizens, rests on the principles of deliberation, transparency, social justice, and direct citizen involvement in selecting policy outcomes (ABERS, 2000; BAIOCCHI, 2005; GOLDFRANK, 2007; WAMPLER and AVRITZER, 2004). More than 200 PT mayors and even a few governors have adopted Participatory Budgeting. The PT also succeeded in the 1990s at developing other innovative policies, such as School Scholarship (bolsa escola), which - from its inception in Brasília - provides targeted funds for low-income families to entice them to ensure that their children attend school regularly. While national PT legislators constantly demanded investigations into corruption by the ruling parties, subnational PT administrations let the party demonstrate its reformist credentials by illustrating that it was 
capable of governing creatively and responsibly. By the time of the 2002 election, public opinion polling demonstrated that Brazilians judged the PT to be the country's most honest party by a wide margin, which was one factor among many in Lula's favour in his fourth run at the presidency (GOLDFRANK, 2004, p. 207-208).

\section{Campaign Costs}

To win, Lula needed money. Our starting point for examining the PT's unexpected descent into the politics of the expected is to note that Brazilian elections are comparatively expensive, at least as expensive as those in the United States, and possibly more (SAMUELS, 2001, p. 33). An avowedly socialist party like the PT in an unequal capitalist country like Brazil could only raise relatively small amounts of money, especially given a law prohibiting union donations. According to David Samuels' (2001) exhaustive study of Brazilian campaign finance, corporations provide by far the most funds, which helps to explain why PT candidates for federal deputy received on average eleven times less money than non-left candidates in 1994, and six times less in $1998^{2}$. In the 1989 , 1994, and 1998 presidential campaigns, the winning candidates vastly outspent Lula. In 1994, the first year campaign contributions were made public, Fernando Henrique Cardoso officially received (and likely spent) more than twenty times as much as Lula, and received more than eighteen times as much in $1998^{3}$. In each race, Cardoso won in the first round. The other three major parties in Brazil - the PSDB (Party of Brazilian Social Democracy), the PMDB (Party of Brazilian Democratic Movement), and the PFL (Party of Liberal Front) - maintained strong and deep ties to Brazil's industrial and agricultural elites, which obviously eased their campaign financing burdens.

The campaign finance story changed dramatically in 2002, however, with Lula officially outspending all the other candidates, including his top competitor, José Serra, who was Cardoso's intended successor. According to the Superior Electoral Court's records, Lula

\footnotetext{
${ }^{2}$ Our calculations from Samuels (2001, p. 39).

${ }^{3}$ Our calculations from Samuels (2001, p. 31).
} 
spent nearly 40 million reais compared to Serra's $R \$ 35$ million, and outspent his other main competitors by two-to-one and ten-to-one margins (www.tse.gov.br). This official reversal of fortunes is interesting in its own right, with Lula's campaign spending jumping from below $\mathrm{R} \$ 5$ million in 1994 and 1998 to nearly R\$ 40 million; but the scandal is in the unofficial figures, where it is estimated that Lula's campaign raised $R \$ 200$ million in off-the-books donations $(A T T U C H, 2006$, p. 16). How did Lula's campaign coffers - official and otherwise - suddenly swell? As philosopher and former PT voter Ruy Fausto argues, after the PT's efforts to legalise union contributions failed, and with the party growing and needing money for campaigns,

\begin{abstract}
at a certain moment - at whose initiative? businessmen (not sympathetic to the party) became disposed to 'help' the PT[...]. Businessmen do not like to have all their eggs in one basket, and there must have been indications (the lack of reality of the projects) that the PT's revolutionary discourse did not have much future (FAUSTO, 2005, p. 211).
\end{abstract}

This interpretation is seconded by one of the investigative journalists who broke the scandal in mid-2005, Leonardo Attuch, who adds that those who spent millions to prevent Lula from winning in the earlier races, financed him in 2002 as an insurance policy (ATTUCH, 2006 , p. 16, 28-29). Attuch notes that the financiers gave equally to Serra's campaign (his inside sources estimate that Serra also received roughly $\mathrm{R} \$ 200$ million extra-officially) and that they generally preferred to donate off the record.

Illegal contributions to Lula's 2002 campaign were the precursor to a bigger scandal, the illegal cash payments to congressional allies during Lula's presidency. When the election was over, despite its fundraising success, the PT still owed $R \$ 20$ million in presidential campaign costs and some $\mathrm{R} \$ 35$ million for governors' races (ATTUCH, 2006, p. 37). In 2003, the PT Treasurer, Delúbio Soares, began engaging in unusual financial transactions with Marcos Valério Fernandes Souza, a marketing executive whose firms secured loans to cover the 
campaign expenses of the PT, and soon thereafter, its allies ${ }^{4}$. Drastically simplifying, the money path operated like this: Souza's publicity firms took out loans for or with the PT; the PT used the funds to pay its 2002 national campaign debts and its 2004 municipal campaign expenses and to provide campaign funds to members of parties allied with the PT in congress, such as the PMDB, PP, PL, and PTB; and Souza's publicity firms received contracts from federal government agencies, the funds of which they are assumed to have used in part to pay off the loans.

Clearly, the 2002 campaign was a turning point in PT finances, and a key part of the mensalão scandal, but while this look at campaign costs answers some questions, it raises a host of others. Why did the PT's campaign treasurers take the risk of illegal donations? Was this a new practice in 2002 or did it build on past corruption? And why did the PT pay off members of other parties as well?

\section{The Consolidation of the Majority Faction: Moderating (and Corrupting?) the PT}

The second explanatory thread concerns the group that controlled the PT, the Campo Majoritário. This faction, tied to Lula and led by José Dirceu, gained the upper hand within the PT in 1995 and was able to engage in political strategies of its choosing, such as focusing resources on executive elections, pursuing alliances with centrist and catch-all parties, and adopting moderate platforms. Since 1984, the PT has held regular elections for its national, state and local leadership positions. At the national level, a majority coalition, first called Articulação and later expanded to become the Campo Majoritário, won eight of the party's nine internal elections, with Lula named party president for most of the 1980s and early 1990s. Since 1989, Lula occupied a centre-right position within the party and he aligned himself with the right groups to ensure control of the party. The left wing of the

\footnotetext{
${ }^{4}$ In June 2005, bank documents were revealed to the press that showed Souza as a guarantor on loans to the PT, alongside the party president, José Genoíno, and treasurer, Soares, and that one of Souza's publicity firms, SMP\&B, had made monthly payments on the loan. At the same time, Souza's firms had large contracts with the federal government (http://www1.folha.uol.com.br/folha/brasil/ult96u70166.shtml). For details on the money trail, see Flynn (2005, p. 1236-1238).
} 
party won the party's presidency one time, in 1993, which left it in control for the 1994 national election. The 1994 campaign was disorganised, with leadership being shared by three different individuals. The 1994 election was a humiliating loss for Lula, as Cardoso rode the success of a new economic plan, the Plano Real, to a convincing presidential victory. Lula strongly opposed the Plano Real and its perceived success left him looking out of touch with average Brazilians.

The alleged incompetence of the PT's left-wing and Lula's vow to never again to run for president without direct control over his campaign led to the 1995 internal party elections that would dramatically re-shape the PT. For those elections, Dirceu helped create the Campo Majoritário by uniting the centre and right factions of the party; he emerged as the PT's National President and held that position for the next seven years. Dirceu used his victory to consolidate the power of the centrist group, creating a party within a party to ensure loyalty to him as well as building alliances at the PT's local and state levels to ensure that Lula's group would continue to control the party (FLYNN, 2005, p. 1254). Under the direction of Dirceu's faction and over the objections of the left factions, the PT: 1) moved farther away from its ground-up, social movement strategy and instead concentrated its energy and resources on winning elections for mayors, governors, and the presidency; 2) moderated its national campaign platforms; and 3) began entering into electoral coalitions with parties that previously had been vetoed as too corrupt, personalist, centrist, or clientelist by the PT's leftist factions.

By 2002, the PT's make-over was complete, as Lula's campaign made clear. The massive rallies and get-out-the-vote efforts conducted by thousands of the PT members in the past were replaced by slick television spots and giant show-mícios (concerts by national music stars). Lula did not mention revolution or socialism, but rather respect for international contracts and International Monetary Fund (IMF) agreements. The campaign slogan was Lulinha - paz e amor (Little Lula - peace and love). And as running mate, Lula selected the owner of one of Brazil's largest textile manufacturers, José Alencar, with a net worth 
several hundred million dollars. Alencar brought his centre-right Liberal Party into the PT-led coalition fronting Lula.

While some see the PT's growing moderation and the everincreasing dominance of the Campo Majoritário as results of internal party democracy (SAMUELS, 2004), many other observers and PT insiders, especially on the left, argue otherwise (FLYNN, 2005; MORAES, 2005; WAINWRIGHT and BANFORD, 2006). These critics argue that the Campo Majoritário's external and thus internal victories were aided by the same kinds of slush funds (or caixa dois) that apparently helped Lula's 2002 campaign. In other words, they claim that the scandals that rocked Lula's administration were similar to the arrangements that had been used by the Campo Majoritário to consolidate its control of the PT. The more successful a faction's candidates were in winning executive offices (governors and mayors), and to a lesser extent, legislative offices, the more paid government positions the faction could offer its members and potential recruits from other factions, and in turn, the better it could perform in internal elections. This does not imply that the PT's emphasis on honesty and transparency was a farce, but that the political group in control of the PT, the Campo Majoritário, was willing to use strategies previously rejected by the PT to consolidate its control.

As Moraes explains, Campo Majoritário leaders created a "parallel finance network" that "operated as an instrument of discrimination and internal privileges without the knowledge of the collective decisionmaking bodies", directing both official and unofficial resources to party moderates (MORAES, 2005, p. 196-197). This explanation echoes the complaints by leaders of the PT's left factions. They claim that "the Campo Majoritário built its own political machine within the party to advance its aim of achieving more flexible policies" and that "some sectors of the party started to have incredibly well-funded campaigns" (WAINWRIGHT and BANFORD, 2006, p. 21-22; also 23, 25-26, 33). Thus, Dirceu consolidated the Campo Majoritário's control over the PT, apparently utilising similar tactics that would be used to carve out a voting majority in congress during Lula's Presidency. For the left critics, 
then, Lula and Dirceu pulled the party to the centre using underhanded methods, rather than being pushed by the base.

There is some evidence to support the critics' position. Already for the 1998 elections, the PT top leadership overrode the wishes of the left factions and a good part of the party base, at least in its coalitional decisions. The Campo Majoritário leaders decided to ally with the PDT (Democratic Labour Party), a populist, nationalist party that continued to rely on traditional Brazilian political practices of clientelism and personalism. In exchange for accepting PDT leader Leonel Brizola as his running mate, Lula and the PT had to give up running their own candidate for the governorship of Rio de Janeiro, but could name the candidate for vice-governor. The local PT in Rio refused to accept this deal and sought to run its own candidate for governor. Indeed, the left factions only approved electoral alliances with leftist parties or progressive factions of centrist parties; they also placed great emphasis on only working with clean and honest parties and politicians. Nonetheless, national PT leaders led by Dirceu forced Rio's PT leadership to withdraw their candidate and support the PDT. Though Lula lost the presidential race, the PDT-PT ticket won the governor's race in Rio, and it was there that the first corruption scandal linked to Dirceu came to light. In 2004, a videotape surfaced showing Dirceu's top aide - then head of Rio's state lottery - asking for donations from the owner of a bingo hall who was reputed to have strong mafia ties ${ }^{5}$.

Evidence of earlier corruption within the PT also exists at the municipal level, especially in the cities controlled by Campo Majoritário leaders (see below). Although the PT sought to direct attention to its most successful cases of clean and participatory government, and especially Porto Alegre, other experiences were far less successful (WAMPLER, 2007). The PT had sufficiently strong internal discipline that 100 per cent of large municipalities (defined as more than 100,000 residents) that they won in 1996 and 2000 adopted Participatory Budgeting, which was partially responsible for the PT's reputation for good government and had become virtually synonymous with the PT

${ }^{5}$ The scandal was first reported in Época (Feb. 11, 2004), Issue 300. 
way of governing (WAMPLER and AVRITZER, 2005). The municipalities of São Paulo, Belo Horizonte, Santo André, and Ribeirão Preto all adopted PB under PT governments, but none of these programs produced levels of transparency comparable to Porto Alegre. It is now increasingly appearing that Porto Alegre's PB is an exceptional case that is far more transparent and has a stronger commitment to social justice and deepening of democracy than most other PB cases (WAMPLER, 2007). The lack of widespread knowledge about other PT-run cities allowed the PT to argue that the positive experience in Porto Alegre was being replicated across Brazil, thereby helping the party build a coherent myth that the PT way of governing was based on transparency, openness, and the deepening of democracy. The point here is that the PT branded itself as a participatory, democratic, clean, and transparent party and often used the successes of Porto Alegre to demonstrate how well PT officials could implement innovative policies to transform Brazilian life.

The municipalities of Santo André and São Paulo illustrated the difficulties faced by the PT as they sought to implement innovative policies at the local level that would help to extend the social struggle into the state but also organise themselves for key national and state elections. Both municipal governments had PT mayors in 2001 and 2002 in the run-up to the 2002 presidential election. Both governments adopted Participatory Budgeting but neither government invested the necessary time, energy or financial capital to make them successful (WAMPLER, 2007). Pedro Pontual, who directed PB in Santo André from 1997-2002, conceded that "after a project was approved by the PB council and entered the budget, we didn't really follow it anymore. We didn't really understand how a public policy was developed and implemented" (Pontual, 2003). In São Paulo, after Marta Suplicy was elected mayor in 2000 , she relied on a patronage system that had been created in the 1950 s but had been rejected by the previous PT mayor, Luiza Erundina (1989-1992). Mayor Suplicy turned over parts of the mayoral administrative apparatus to political allies to ensure their support. Her support for PB was lukewarm, at best, and the process 
there lacked transparency (WAMPLER, 2007). São Paulo and Santo André were two of the most important municipalities to then-candidate Lula as he began his run for the presidency; the demands of running campaigns trumped the effort to deepen democracy, promote social justice, and create basic transparency. In other words, the PT in some cities was already moving away from an emphasis on participatory, clean, transparent politics. The party used its control of powerful São Paulo municipalities to provide support for Lula's campaign. An emphasis on the importance of innovation and participatory politics were still present elsewhere in Brazil (Recife, Belo Horizonte, Porto Alegre), but it was not a principal focus of the São Paulo faction of the Campo Majoritário.

The PT way of governing, then, was adopted by many of its municipal governments, but that is only part of the picture. Many of Lula's 2002 campaign fund-raisers were active in the PT's local administrations, especially in the state of São Paulo, where they engaged in the same sorts of financial practices for which they are now being investigated (ATTUCH, 2006; see also Folha de São Paulo, $10 / 31 / 2005$, p. 1, A7). Lower-level PT officials in municipalities appear to have been involved in financial transactions that gave them access to revenues from public and private bus companies, which were sources of the PT's caixa dois as well as more ordinary kickback schemes. In Ribeirão Preto, for example, Rogério Buratti, a former advisor to then PT mayor Antônio Palocci (1993-1996; 2000-2002), was imprisoned temporarily in 2005 on charges of money laundering in transactions with bus companies and was accused of overbilling for garbage collection services (Folha de São Paulo 8/18/2005, p. 1, A4). Buratti implicated Palocci, who was ultimately forced to resign as Lula's finance minister in March 2006, because of these and related charges of operating a mensalão scheme of his own when he was mayor (Jornal do Brasil 3/28/2006, p. 1). Corruption in the PT thus began prior to its 2002 presidential victory, but was accompanied by genuine efforts to overhaul local political and policy processes. Within the PT there are reformist and corrupt sectors at all levels of the party organization, which suggests 
that the PT carried both reform-minded and business-as-usual members into the presidency.

If the PT's left wing found itself consistently out of power and outmanoeuvred by the Campo Majoritário, why did it stay in the party? Leftist factions also engaged in internal party battles to obtain government positions and increase the size of their internal voting blocs. The left factions generally garnered around 45 per cent of the vote for the PT's national presidency, which gave them hope that they would win at some not too-distant point. The left wing of the party also had nowhere else to go; the PSTU, which some purged PT members founded in 1993 as a left alternative, has never received enough votes to elect even one congressional representative (FREIRE DE LACERDA, 2002) ${ }^{6}$. The relatively high level of internal support given to the left factions also established their continuing importance within the party, which meant that the Campo Majoritário could not ignore them in an eventual distribution of national government posts. This leads to our third and fourth interweaving strands: economic constraints and multi-party presidentialism.

\section{Maintaining Austerity and Alliances in a Multi-Party Presidential System}

After Lula won in October 2002, he and his top advisors had two months to put together his cabinet before the January inauguration. They faced several countervailing pressures. First, as detailed below, in order to placate the financial markets, Lula had committed to maintaining fiscal austerity during his campaign, and his cabinet and policy choices were expected to reflect this commitment. Second, Lula not only had to satiate the Campo Majoritário's desire for cabinet

\footnotetext{
${ }^{6}$ Two years after Lula's victory in 2002, several members of left factions within the PT bolted the party following the PT's expulsion of a senator and three federal deputies who had voted against a government-proposed social security reform. They formed a new party, the PSOL (Party of Socialism and Liberty), which managed to win three seats in the chamber of deputies in the 2006 elections (with just 1.2 per cent of the vote). The PSOL's presidential candidate came in third, with roughly seven per cent of the vote. Some charismatic politicians of the left might find a home in the PSOL, but the poor showing of their legislative candidates will likely make PT dissidents more carefully consider their attacks on President Lula's policies.
} 
positions but also appease the left factions, who had swallowed his overtures to the right and compromises with capital in the hope of rewards. Third, Lula was expected to dole out posts to members of his electoral alliance, as is traditionally done in Brazil's multi-party system, where no president arrives to office without a coalition behind him (HUNTER and POWER, 2005). A fourth apparent consideration was that, as mentioned above, the PT's coffers were $\mathrm{R} \$ 55$ million in the red. The solution, it seems, included increasing the size of the cabinet, up to 36 members from Cardoso's 21, and the mensalão scheme, involving various government offices, public contracts, and regular side payments to those under-rewarded with administrative posts (RAILE, PEREIRA, and POWER, 2006). The 36 cabinet slots were used to reward members of the PT and their closest allies while the mensalão scheme was used to attract potential allies in the national legislature.

As the early opinion polls of the 2002 presidential campaign showed Lula gaining a strong lead, foreign investors began showing signs of nervousness about the future Brazilian government's ability and willingness to make its debt payments. Their fears were stoked by Argentina's default in 2001, Brazil's low level of reserves, and by the PT's prior proposals for debt moratoria or renegotiations. Despite Lula's moderate platform and business suits, as his poll numbers strengthened, Brazil's currency weakened and investment banks stopped recommending Brazilian bonds. Martínez and Santiso cite a report by BCP Securities from late May called Da Lula Monster in which analyst Walter Molano writes: "there seems to be a sense of panic as economic agents realise that Lula will win the elections" (MARTINEZ and SANTIZO, 2003, p. 371). In June, Lula's campaign issued a statement promising that, if elected president, Lula would not employ capital controls, would not renegotiate the external debt, and would maintain the Cardoso government's financial commitments. This Letter to the Brazilian People (Carta ao Povo Brasileiro), derided as the Letter to Calm the Bankers (Carta para Acalmar Banqueiro) by its critics, seems not to have had a tremendous effect on foreign investors, though it caused a stir in Brazil. By the following month, Brazil's currency, the real, had 
dropped to 3.50 to the dollar from a level of 2.30 at the start of the year, investment banks continued downgrading Brazil's bonds, and capital flight doubled from June's levels (MARTINEZ and SANTIZO, 2003, p. 370, 373). It was not until the Central Bank raised interest rates, the IMF announced a $\$ 30$ billion loan that had the explicit support of the US government, and Lula and the other presidential candidates agreed to respect the terms that the real recovered some ground (COUTO and BAIA, 2006, p. 16; MARTINEZ and SANTISO, 2003, p. 374). The IMF loan was structured so that most of the money would be dispersed well after the inauguration in 2003 to encourage the new president to honour the agreement's targets for a budget surplus of 3.75 per cent (dedicated to repaying the debt) and a low inflation rate.

Thus, once elected, Lula found the government in a fiscal straitjacket, as Samuels (2003) predicted for Cardoso's successor. Samuels details several vicious circles trapping Brazil's government: to maintain stable exchange and inflation rates as well as attract foreign investment, Lula would have to maintain high interest rates; in turn, this increases government debt, which scares off investment dollars; and to jumpstart the stagnant economic economy and attend to the needs of poor Brazilians, Lula would need to increase social spending, yet this interferes with the budget surplus requirements to pay off the debt (SAMUELS, 2003). Samuels argues: "If the government does not maintain budget surpluses, the debt level may rise, creating downward pressure on the real and thus upward pressure on prices and interest rates, perpetuating or even worsening the vicious circle of debt" (SAMUELS, 2003, p 567).

The tight constraints on Lula's future administration had been made clear by the financial markets during the campaign, yet they were still jittery about Lula's policy direction after the election. To end all doubts, Lula's team sent even stronger signals about the PT administration's commitment to austerity: it announced that the government's target budget surplus would be 4.25 per cent, even higher than the IMF had required, and that the top economic positions would be filled by businessmen and technocrats approved of by Wall Street and 
BOVESPA. Eight members of Lula's 36-member cabinet were technocrats without party affiliation, and nine of 37 if one includes the President of the Central Bank (COUTO and BAIA, 2006, p. 7).

In order to sell the PT left on the capitulation to the financial markets, Lula's group took two tacks. It presented the policy continuity with the Cardoso government as both unavoidable, given economic constraints, and short-term (WAINWRIGHT and BANFORD, 2006, p 28). And it gave several cabinet seats to leaders of the left factions and to more leftist members of the Campo Majoritário. After ensuring a market-friendly economic team and a space for the left, Lula's group needed to secure the Campo Majoritário's dominance in the government - granting it twelve of the PT's 20 seats - but this left little room for the eight other parties that had supported Lula in round two of the presidential race. In Lula's first cabinet, each alliance partner (save one tiny party) only received one seat. More importantly, the two largest potential congressional allies for the PT government were initially excluded (COUTO and BAIA, 2006, p 4, 7).

Typically, Brazilian presidents distribute cabinet seats to members of their coalition in order to build a congressional majority. In the country's democratic history (including the Second Republic from 1946-1964), only one president's party has had a majority on its own (which lasted just a year), given that more than a dozen parties are generally represented in the congress. In the 2002 election, nineteen parties won seats in the Chamber of Deputies, and ten in the Senate. The PT was the largest party in the Chamber, but had just 91 seats, a great distance from the 257 that it needed to establish a majority. Including Lula's alliance partners, the PT congressional coalition only reached 219 seats. Eventually, Lula brought the third-largest party in the Chamber, the PMDB (Party of the Brazilian Democratic Movement), into his cabinet in order to achieve a congressional majority, but he only gave the party two seats. According to Raile, Pereira and Power (2006), the disproportionality between the number of cabinet seats granted to Lula's coalition members and the number of congressional seats coalition members controlled created the necessity of side-payments. 
Like Goes (apud FLYNN, 2005), they compare the party composition in the cabinets of Lula and Cardoso. Raile, Pereira and Power (2006) show that Lula's cabinet was more disproportional than any other since 1988, as well as being virtually monopolised by the president's party; this decreased his ability to keep his coalition partners happy - and voting with him in congress- and pushed the government to buy loyalty by other means (RAILE, PEREIRA, and POWER, 2006) ${ }^{7}$.

During his hearing before the Congressional Investigation Committee, the PT's treasurer, Soares, admitted providing money to congress members in the PT and other parties, but he argued that the payments were not bribes but were to help with campaign costs (Estado de São Paulo, 7/21/2005, p. 1, A5). We may never know who invented the idea of side-payments. Was it the PT leadership, searching for a way to maintain its internal and external coalitions? Or was it Souza, who presented the idea to the PT treasurer as a way out of campaign debts both for the PT and its allies? The latter idea sounds plausible, given that Souza has been formally charged with orchestrating a similar scheme for the PSDB in Minas Gerais four years earlier. ${ }^{8}$ One thing is clear: these needs - for a way to reward internal and external allies and for funds to cover campaign costs - emerged simultaneously. Together, they pushed the PT leadership into risking the party's reputation for clean government. The Campo Majoritário's support for illegal activities temporarily strengthened the party by retiring campaign debts while also allowing President Lula to cobble together legislative majorities. The PT, formed with a large union and social movement base to transform Brazil, was ultimately induced by economic, institutional, and social pressures to engage in the very behaviours that the party had been established to reform.

\footnotetext{
${ }^{7}$ Strengthening this interpretation is the fact that large bank withdrawals made by Souza's firm in 2003 and 2004 coincide with important votes in congress (CORREIO BRAZILIENSE, jul. 05, 2005, p. 1-6).

${ }^{8}$ According to the Attorney General who brought the charges in November 2007, Antonio Fernando de Souza, the Minas operation "served as the 'origin and laboratory' of the PT mensalão" (ESTADO DE SÃO PAULO, nov. 23, 2007, p. 1, A4-A6).
} 


\section{Conclusion}

The PT's fall from grace is best explained by the domestic institutional pressures that induced party leaders to change their political strategies, by national and international markets that provided a limited range of options, and by intra-party conflicts regarding the strategies that should be utilized to govern effectively and win national power. These are overlapping factors that led the PT to turn to illegal activities as a way to fund their campaigns and establish legislative majorities. Recognizing the party's extreme disadvantage in campaign finance, and thus in elections generally, the dominant faction's leaders began moderating the PT's rhetoric and policies in order to attract campaign contributions both on and off the books, first at the local level in select cities, and later at the national level. The Campo Majoritário leadership used its financial advantages over the other factions to reward its supporters and enhance its position in internal struggles concerning the party's ideological direction. The negative reaction to Lula's candidacy by international financial markets strengthened the Campo Majoritário's efforts to push the PT to the centre and constrained Lula's policy and cabinet choices. At the same time, the left factions' internal strength meant that the Lula government would have to reward it somehow as well, and cabinet seats became the reward. As Lula took office, these pressures combined with the party's campaign debts and the need to build a legislative majority without using the traditional method of distributing cabinet positions pushed the leadership to move beyond taking illegal campaign contributions and supporting the Campo Majoritário's own members to buying the support of other parties.

As of December 2007, the only formal punishment of those involved in the mensalão was the expulsion from Congress of several deputies (from various parties, including the PT) and the expulsion from the PT of Soares. Many other PT figures resigned from their positions in the Congress, in the party (including the PT president José Genoíno), and in the administration (including the chief of staff José Dirceu as well as the finance minister Antônio Palocci). In August 2007, the Federal Supreme Court indicted 40 politicians and businessmen in relation to the 
mensalão, including Soares, Genoíno, Dirceu, and Souza. However, as Taylor (Forthcoming 2009) notes, despite several highly publicised corruption scandals, including the impeachment of a sitting president in 1992, very few national politicians have served jail time since the return to democracy. Taylor argues that Brazil's accountability institutions emphasise investigating corruption allegations, but none focuses on ongoing monitoring to prevent corruption or on punishing those found guilty. The impunity of Brazilian politicians surely contributed to the calculations of the individual leaders who orchestrated the mensalão. Indeed, the principal players linked to the mensalão will likely emerge relatively unscathed, without paying much of a price for their involvement.

Results of the 2006 general elections mostly bear this out. Genoíno and Palocci were both elected as federal deputies, as was Genoíno's brother (whose aide had been caught with money in his underwear). Lula, who faced threats of impeachment from the opposition parties after the scandal broke, went on to win re-election, again in the second round, and again with $61 \%$ of the valid vote. In their analysis of the 2006 race, Hunter and Power (2007, p. 11-14) suggest that Lula's success in avoiding the taint of scandal derived from voters' lack of access to information, low levels of education, and the material gains among Brazil's largest constituency: the poor, especially the rural poor in the Northern and Northeastern states. Lula appears to have been punished by more highly educated, well-to-do voters, especially in the richer Southern states that contribute fewer voters overall, but Lula's appeal as a member of the working class who had improved the purchasing power of low-income Brazilians, led to his wide-spread support among poor voters in the North and Northeast (SAMUELS, 2008).

However, the PT as a collective has paid dearly. Many of its top leaders resigned. Eight deputies, a senator, and several hundred prominent members abandoned the PT to create a new party on the left, the PSOL (Party of Socialism and Liberty), which won enough votes to prevent a first-round victory for Lula in the 2006 presidential campaign 
(see fn 6). Their exit began before the mensalão broke, but the scandal and the PT's unwillingness to change leadership afterwards helped push them to the door. Support from hundreds of thousands of social movement activists has also waned, as the largest movement organizations have published condemnations of the PT's failures in office (HOCHSTETLER, 2006 p. 21-22). Major social movements did back Lula in the second round of the 2006 election, but more as a defence against the alternative than as an enthusiastic endorsement. If a non-PT ethical movement develops, it will most likely emerge from these civil and political society sectors, as they work to check abuses of power committed by government officials, including their former allies now working within Lula's government.

In the 2006 congressional elections, the PT lost over two million voters (13 percent of its 2002 electorate) and saw the party bench reduced to under 16 percent from over 18 percent of the seats in the lower house of congress, where it no longer holds even a plurality. The 2006 election results revealed that the PT's constituency has shifted, with the strongest base of support moving from the PT's origins in the richer and more industrialized southern states like São Paulo and Rio Grande do Sul to the poorest regions of the Northeast and North, where the party won five governorships (including Bahia, one of the country's most populous) and Lula received his highest vote shares ${ }^{9}$. This shift was likely driven by the PT government's creation of the beginnings of a welfare state - particularly the bolsa família (family grant) program. The ten states where Lula received the highest percentage of the vote in the first round of the election were the ten states with the highest percentages of families benefited by the bolsa familia (NASCIMENTO, 2006). It appears that the principal element left from the PT way of governing is (re)distribution, albeit in small amounts. Lula's re-election in 2006 offers hope to only the most optimistic that the PT will be able to transform traditional political processes that the PT had long derided.

9 Interestingly, in the legislative elections, the PT continued to perform better in its traditional urban, industrialized strongholds than in the rural areas of the North and Northeast (HUNTER and POWER, 2007, p. 8) that now favor Lula and PT candidates for governor. 
The PT lost its ability to distinguish itself from other Brazilian parties on ethical grounds. In the 2006 election campaign, Lula rebutted the opposition's accusations against him with charges of his own regarding their alleged corruption. The PT campaign accused Lula's main opponent, Geraldo Alckmin (Party of Brazilian Social Democracy, PSDB), of covering up corruption during his term as governor of São Paulo based on the PSDB's record of blocking dozens of state congressional investigations. And Lula revived claims of corruption under the Cardoso presidencies, including allegations that deputies were paid to support the amendment allowing presidential re-election, that banks received preferential treatment during the devaluation of the real, and that the regional development agencies Sudam and Sudene illegally diverted public resources.

Lula's election as president in 2002 offered petistas the hope of increasing their political power and transforming Brazilian politics. While the PT will continue as one of the country's most important political parties, Brazil has transformed the PT more than the PT has transformed Brazil. Most importantly, the PT has lost its reputation for clean government. The PT way of governing was explicitly designed to allow interested citizens to be involved in public expenditures planning and day-to-day monitoring. The resistance of the PT national leadership to initiate any substantive reform efforts in these directions suggests that the impulse to reform Brazilian institutions is no longer a core feature of the PT's politics. The absence of a drive to overhaul Brazilian politics is perhaps the most significant result of Lula's ascendancy to the presidency; the party that most stridently sought reform is now led by individuals and groups who are quite willing to play politics using longstanding traditions and practices. The PT set out, in the early 1980s, to finish off corruption and lead Brazil in a new direction. Having gained the presidency twenty years later, the apparent willingness of PT leaders to use corrupt methods as basic components of their electoral and governing strategies suggests that the distinctive PT way of governing has ended and that Brazil's traditional politics remain entrenched. Further scandals after the mensalão - the ambulance mafia scandal 
involving scores of congressional representatives from several parties, including the PT, and dossier-gate, in which members of Lula's reelection campaign attempted to purchase apparently fraudulent evidence of a rival's involvement in the ambulance mafia - continue to tarnish the PT's image, probably making future attempts by the party to renew its anti-corruption stance unfeasible. Indeed, from being perceived as Brazil's most honest party, the PT is now seen as being the most corrupt (Fundação Perseu Abramo, 2006).

Efforts to promote the PT way of governing are likely to be taken up outside the PT or far from the national leadership. It is possible that reform movements will arise anew within the PT. Efforts in this direction began in 2005 for the PT's internal elections, as candidates for the party presidency called for a refounding of the party, yet the Campo Majoritário's candidate won. In early 2007, in anticipation of the Third Party Congress to be held in August, some PT factions began launching calls for ending the impunity of those involved in the mensalão and ending the dominance of the Campo Majoritário and the São Paulo group (Folha de São Paulo, 2/11/2007,p. 1, A4; Gazeta Mercantil, 4/5/2007, p. A8). Yet the major ethics reform candidate did not even make it to the second round of internal elections for president in December. Still, even if internal reformers are able to wrest control away from the Campo Majoritário, they will now have a more difficult time convincing a sceptical public that the PT is different from other political parties. The national PT leadership has mired the party in corruption, thereby suggesting that non-PT actors will take the lead in the effort to promote transparency, honesty, and openness in governmental affairs.

Benjamin Goldfrank é doutor em Ciência Política pela University of California, e professor na University of New Mexico.

E-mail: goldfrbe@shu.edu

Brian Wampler é doutor em Ciência Política pela University of Texas, e professor na Boise State University.

E-mail: bwampler@boisestate.edu 


\section{References:}

ABERS, Rebecca Neaera. Inventing Local Democracy. Boulder: CO. Westview Press, 2000.

AMES, Barry. The Deadlock of Democracy in Brazil. Ann Arbor: University of Michigan Press, 2001.

ATTUCH, Leonardo. A CPI que Abalou o Brasil: Os bastidores da imprensa e os segredos do PT. São Paulo: Futura, 2006.

BAIOCCHI, Gianpaolo. Militants and Citizens: The Politics of Participatory Democracy in Porto Alegre. Stanford, CA.: Stanford University Press, 2005.

CORREIO BRAZILIENSE. Brasília, jul 05, 2005. p. 1-6.

COUTO, Cláudio; BAIA, Paulo. Lula's Administration: The Limits of Change. In: Meeting of the Latin American Studies Association, 15-18 March 2006. San Juan, Puerto Rico: LASA, 2006.

ÉPOCA. Issue 300, feb. 11, 2004.

ESTADO DE SÃO PAULO. São Paulo, jul. 09, 2005. p.1.

. São Paulo, jul. 21, 2005. p. 1, A5.

. São Paulo, nov. 23, 2007. p. 1, A4-A6.

FAUSTO, Ruy. Para além da gangrene. Lua Nova, São Paulo, 65, p. 203228, may.-aug. 2005.

FLYNN, Peter. Brazil and Lula, 2005: Crisis, Corruption and Change in Political Perspective. Third World Quarterly, London, v. 26, n. 8, p. 1221-1267, nov. 2005.

Folha de São Paulo. São Paulo, jul. 02, 2005. Disposable in: <http://www1.folha.uol.com.br/folha/brasil/ult96u70166.shtml>.

Accessed in: aug. 17, 2006.

. São Paulo, aug. 18, 2005. p. 1, A4.

. São Paulo, oct. 31, 2005. p. 1, A7.

. São Paulo, feb. 11, 2007. p. 1, A4.

FREIRE DE LACERDA, Alan Daniel. O PT e a unidade partidária como problema. DADOS, Rio de Janeiro, v. 45, n. 1, p. 39-76, 2002. 
FUNDAÇÃO PERSEU ABRAMO. Governo Lula, imagem dos partidos e cultura política. 2006. Disposable in: <http://www2.fpa.org.br/portal/modules/wfdownloads/viewcat.php?cid $=65>$. Accessed in: dec. 14, 2007.

GAZETA MERCANTIL. São Paulo, apr. 05, 2007. p. A8.

GOIS, Ancelmo. Apresentação: O Samba do mensalão. In: CAMAROTTI, Gerson; PEÑA, Bernardo de la (Orgs.). Memorial do escândalo: os bastidores da crise e da corrupção no governo Lula. São Paulo: Geração Editorial, 2005. p. 13-14.

GOLDFRANK, Benjamin. Conclusion: The End of Politics or a New Beginning for the Left. In: CHAVEZ, Daniel; GOLDFRANK, Benjamin (Eds.). The Left in the City: Participatory Local Governments in Latin America. London: LAB/TNI, 2004. p. 193-211.

- The Politics of Deepening Local Democracy: Decentralization, Party Institutionalization, and Participation. Comparative Politics, New York, v. 39, n. 2, p. 147-168, jan. 2007.

HOCHSTETLER, Kathryn. Organized Civil Society in Lula's Brazil. Meeting of the Latin American Studies Association, 15-18 March 2006. San Juan, Puerto Rico: LASA, 2006.

HUNTER, Wendy; POWER, Timothy. Lula's Brazil at Midterm. Journal of Democracy, Baltimore, v. 16, n. 3, p. 127-139, jul. 2005.

Rewarding Lula: Executive Power, Social Policy, and the Brazilian Elections of 2006. Latin American Politics \& Society, Miami, v. 49 , n. 1, p. 1-30, spring 2007.

JORNAL DO BRASIL. Rio de Janeiro, mar. 28, 2006. p. 1.

KECK, Margaret. The Workers' Party and Democratization in Brazil. New Haven: Yale University Press, 1992.

MARKUN, Paulo. O sapo e o príncipe:personagens, fatos e fábulas do Brasil contemporâneo. Rio de Janeiro: Objetiva, 2004.

MARTÍNEZ, Juan; SANTISO, Javier. Financial Markets and Politics: the confidence game in Latin American emerging economies. International Political Science Review, Montreal, v. 29, n. 2, p. 363-396, jul. 2003.

MORAES, Reginaldo. Notas sobre o imbróglio do Governo Lula, 2005. Lua Nova, São Paulo, 65, p. 179-202, mai.-ago. 2005.

NASCIMENTO, Solano. Bolsa família mostra sua força no primeiro turno. Correio Braziliense, Brasília, 05 de outubro de 2006. Disposable in: 
<http://www.correioweb.com.br/hotsites/eleicoes2006/noticias.htm?ulti $\underline{\mathrm{ma}=2684933}>$. Accessed in: out. 6, 2006.

NYLEN, William. The Making of a Loyal Opposition: The Workers' Party (PT) and the Consolidation of Democracy in Brazil. In: KINGSTONE, Peter; POWER, Timothy (Eds.). Democratic Brazil: Actors, Institutions, and Processes. Pittsburgh: University of Pittsburgh, 2000. p. 126-143.

PONTUAL, Pedro. Interview to Brian Wampler. Sep. 03, 2003.

RAILE, Eric; PEREIRA, Carlos; POWER, Timothy. The Presidential Toolbox: Generating Support in a Multiparty Presidential Regime. Meeting of the American Political Science Association, August 31 September 3, 2006. Philadelphia: APSA, 2006.

SAMUELS, David Julian. Money, Elections, and Democracy in Brazil. Latin American Politics \& Society, Miami, v. 43, n. 2, p. 27-48, summer 2001.

. Fiscal Straitjacket: The Politics of Macroeconomic Reform in Brazil, 1995-2002. Journal of Latin American Studies, London, v. 35, n. 3, p. 545-569, aug. 2003.

From Socialism to Social Democracy: Party Organization and the Transformation of the Workers' Party in Brazil. Comparative Political Studies, v. 37, n. 9, p. 999-1024, nov. 2004.

Brazilian Democracy under Lula and the PT. In: DOMINGUEZ, Jorge; SHIFTER, Michael (Eds.). Constructing Democratic Governance in Latin America. Baltimore: John Hopkins University Press, 2008. p. 152176.

TAYLOR, Matthew M. Corruption, Accountability and Democracy: the Brazilian Experience. In: BLAKE, Charles; MORRIS, Stephen (Eds.). Political Corruption in Latin America: New Research on an Old Problem. (Forthcoming 2009).

TRIBUNAL SUPERIOR ELEITORAL. Disposable in: <http://www.tse.gov.br/eleicoes/eleicoes2002/prestacao >. Accessed in: aug. 17, 2006.

WAINWRIGHT, Hilary; BRANFORD, Sue (Eds.). In the Eye of the Storm: Left-Wing Activists Discuss the Political Crisis in Brazil. Transnational Institute. Disposable in: <http://www.tni.org/reports/newpol/brasildossier.htm>. Accessed in: aug. 17, 2006.

WAMPLER, Brian. Participatory Budgeting in Brazil: Contestation, Cooperation, and Accountabliity. University Park: Pennsylvania State University Press, 2007. 
WAMPLER, Brian; AVRITZER, Leonardo. Participatory Publics: Civil Society and New Institutions in Democratic Brazil. Comparative Politics, New York, v. 36, n. 3, p. 291-312, apr. 2004.

. The Spread of Participatory Democracy in Brazil: From Radical Democracy to Participatory Good Government. Journal of Latin American Urban Studies, New York, v. 7, p. 37-52, fall 2005. 